\title{
AKUNTABILITAS KEBIJAKAN DAN PEMBUDAYAAN PERILAKU ANTIKORUPSI
}

\author{
Zudan Arif Fakrulloh \\ Kementrian Dalam Negeri \\ e-mail:@yahoo.com
}

\begin{abstract}
ABSTRAK
Korupsi merupakan fenomena sosial yang sudah tua, seiring bersama dengan peradaban masyarakatnya. Semakin luasnya kekuasaan negara dalam mengatur kehidupan bermasyarakat-negara seperti sekarang ini, menyebabkan semakin kompleks pula bentuk dan modus korupsi. Dalam rangka pemberantasan korupsi, berbagai upaya telah dilakukan, mulai di era Orde Lama, Orde Baru, maupun Orde Reformasi. Berbagai model kebijakan pemberantasan telah dilakukan termasuk pembentukan Lembaga Ektra (Extra Ordinary Bodies) sebagaimana Komisi Pemberantasan Korupsi (KPK), sampai pada tataran pembentukan budaya anti korupsi melalui Pacta Integritas. Namun demikian masih saja korupsi tetap menggurita, sehingga pemberantasan korupsi dianggap saja Quo Vadis. Perilaku antikorupsi hanya akan terwujud manakala setiap individu masyarakat maupun pejabat lebih takut kepada Tuhan Yang Maha Tahu dibandingkan takut kepada Komisi Pemberantasan Korupsi.
\end{abstract}

Kata Kunci: akuntabilitas kebijakan, korupsi, budaya anti korupsi

\begin{abstract}
Corruption represent the old social phenomenon, along along its society civilization. Progressively broadness of state power in arranging life go into society the state of like this time, causing complex progressively also form and corruption modus. In order to corruption eradication, various effort have been conducted, start in Old Order era, New Order, and also Reform Order. Various model of eradication policy have been conducted by the inclusive of forming Extra Ordinary Bodies as Commission of Corruption Eradication, come up with forming the anti corruption culture through Integrity Pacta. But that way just still be corruption remain to baby-abdominal belt, so that assumed it the just by corruption eradication of Quo Vadis. Anti corruption behavior will only be existed when every individual of society and also functionary more fear to God Which The most Know compared to fear to Commission of Corruption Eradication.
\end{abstract}

Keywords: policy accountability, corruption, anti corruption

\section{PENDAHULUAN}

Kasus bailout dalam rangka penyelamatan Bank Century oleh Bank Indonesia dengan sun ikan dana sebesar 6,7 triliun rupiah membuka sudut pandang yang relatif baru dalam penegakan hukum di Indonesia. Para ahli hukum dan penegak hukum mulai mendiskusikan secara intensif terhadap kebijakan penyelamatan Bank Century yang berimplikasi keluarnya uang negara sebesar 6,7 triliun rupiah. Pertanyaan mendasar yang perlu kita kupas bersama adalah apakah kebijakan yang diambil oleh penyelenggaran negara/pemerintahan dapat dinilai dari aspek Hukum Pidana ataukah hanya implementasi dari kebijakan yang dilakukan secara menyimpang yang dapat dinilai dari aspek Hukum Pidana. Dalam konteks Indonesia, persoalan kebijakan yang berimplikasi pidana hanyalah gunung es dari serangkaian kebijakan di sektor lain seperti sektor pertambangan, kehutanan, pemberian bantuan sosial yang bersumber dari APBD dalam rangka pemenangan pilkada dan lainlain. Kebijakan-kebijakan yang bersifat koruptif masih banyak terjadi dalam penyelenggaraan pemerintahan di Indonesia. Kebijakan yang koruptif dapat terjadi dalam segala lini, mulai dari pembuatan undang-undang, pembentukan regulasi sektoral yang menguntungkan pihak tertentu, sampai dengan pemberian izin tertentu yang dapat merugikan negara.

Secara historis, sejak jaman dahulu kala perbuatan koruptif telah terjadi dalam kehidupan manusia. Hasil temuan Tim Arkeologi Belanda telah menemukan sekitar 150 prasasti "Cunaiform" di Ridka Syria, yang menunjukkan bahwa situs tersebut adalah pusat administrasi peradaban Syria pada abad ke-13 SM. Dalam situs tersebut ditemukan sebuah arsip milik lembaga setara dengan lembaga modern "Kementerian Dalam Negeri" yang berisi 
nama-nama pegawai yang menerima suap termasuk nama-nama pejabat tinggi dan nama seorang putri Assyria (dikutip dari buku panduan Transparency International, 2002).

Label korupsi tidak semata-mata diperuntukkan bagi Pegawai Negeri Sipil, Anggota TNI dan Polri, Pegawai BUMN/BUMD atau Anggota Parlemen Pusat dan Daerah, atau Pejabat dan Pelaku Fungsi Yudikatif atau konglomerat dan badan usaha swasta, namun juga dapat ditempelkan pada semua lembaga dan anggota masyarakat dengan pekerjaan tertentu yang secara langsung atau tidak langsung berhubungan dengan kepentingan publik, seperti misalnya Pengacara, Akuntan Publik, Notaris, dan lain-lain. Hal inilah yang menyebabkan munculnya sinisme bahwa korupsi sudah menjadi budaya, sehingga dikatakan korupsi itu "hal yang biasa", karena terjadi nyaris di semua sektor dan lapisan masyarakat. Perbuatan korupsi menimbulkan inefisiensi dan pemborosan dalam ekonomi, karena dampaknya pada alokasi dana pada produksi, konsumsi, yang mana keuntungan yang diperoleh dari korupsi sudah pasti digunakan untuk keuntungan/kekayaan pribadi.

Pada awalnya penyebab korupsi adalah kemiskinan, sehingga kemiskinan menjadi akar dari masalah korupsi. Hal ini terlihat dari ketidakseimbangan pendapatan dan pengeluaran konsumtif dari para penyelenggara negara. Namun paradigma tersebut telah bergeser karena ternyata perbuatan korupsi itu sendiri telah mengarah pada sektor swasta (konglomerat) dan birokrat tinggi yang level kehidupannya telah bergelimang dengan kekayaan.

Penegakan hukum sebagai pusat dari seluruh "aktivitas kehidupan" hukum yang dimulai dari perencanaan hukum, pembentukan hukum, penerapan hukum dan evaluasi hukum. Penegakan hukum pada hakikatnya merupakan interaksi antara berbagai perilaku manusia yang mewakili kepentingan-kepentingan yang berbeda dalam bingkai aturan yang telah disepakati bersama. Oleh karena itu, penegakan hukum tidak dapat sematamata dianggap sebagai proses menerapkan hukum sebagaimana pendapat kaum legalistik. Namun proses penegakan hukum mempunyai dimensi yang lebih luas daripada pendapat tersebut, karena dalam penegakan hukum akan melibatkan dimensi perilaku manusia. Dengan pemahaman tersebut maka kita dapat mengetahui bahwa problemaproblema hukum yang akan selalu menonjol adalah problema "law in action" bukan pada "law in the books".

Pada saat ini kita dapat mengamati, melihat dan merasakan bahwa penegakan hukum berada dalam posisi yang tidak menggembirakan. Masyarakat mempertanyakan kinerja aparat penegak hukum dalam pemberantasan korupsi, merebaknya mafia peradilan, pelanggaran hukum dalam pengelolaan APBN dan APBD, maupun pembentukan kebijakan yang dilakukan secara sewenang-wenang untuk menguntungkan pihak tertentu. Korupsi telah men-jadi isu sentral dalam praktik hukum dan pemerintahan di Indonesia. Diagnosis perilaku korupsi tampaknya semakin endemis dan seakanakan membudaya dan menjadi epidemis yang merambah dalam segala aspek kehidupan (IGM Nurjana, 2010: 11). Upaya pemberantasan korupsi menjadi sangat problematis yang dipengaruhi dengan berbagai faktor ekonomi dan politik, sosial dan kemasyarakatan, dan meminjam istilah Lawrence Friedmann, problematikanya bersumber pada aspek substansi hukum, struktur hukum dan budaya hukum masyarakatnya serta sarana dan prasarana yang tersedia.

Dari uraian di atas, maka yang menjadi masalah adalah: 1. Apakah yang dimaksud dengan tindak pidana korupsi? 2. Apakah perlunya akuntabilitas kebijakan dalam kerangka tata kelola pemerintahan yang baik? 3.Bagaimana upaya-upaya pemberantasan korupsi?, dan 4. Bagaimana peran Pakta Integritas dalam memerangi tindak pidana korupsi?

\section{PEMAHAMAN DASAR TINDAK PIDANA KORUPSI}

Secara umum dan sederhana korupsi dapat diartikan sebagai penyalahgunaan kekuasan atau kepercayaan untuk keuntungan pribadi. Pengertian korupsi juga mencakup perilaku pejabat-pejabat sektor publik, baik politisi maupun pegawai negeri, yang memperkaya diri mereka secara tidak pantas dan melanggar hukum, atau orang-orang yang dekat dengan pejabat birokrasi dengan menyalahgunakan kekuasaan yang dipercayakan kepada mereka.

Kehidupan korupsi dalam konteks pelayanan publik ini merupakan perbuatan "korupsi administrasi" dengan fokus pada perbuatan perorangan yang memegang kontrol dalam kedudukannya sebagai pejabat publik, sebagai pembuat kebijakan atau sebagai pegawai birokrasi pemerintah, atas berbagai kegiatan dan keputusan.

Semakin meluasnya proyek swastanisasi 
perusahaan negara dan pengalihan kegiatan yang selama ini dipandang masuk dalam lingkup tugas pemerintah ke sektor swasta, dan monopoli penuh atau setengah penuh penyediaan barang publik oleh sektor swasta (misalnya air, listrik, telkom), maka perbuatan korupsi telah merambah juga pada sektor swasta di luar dan di dalam hubungan kerja sektor swasta dengan sektor publik, sehingga perbuatan korupsi kedua sektor ini membawa dampak ne-gatif terhadap kepentingan publik.

Dalam Undang-undang Nomor 31 tahun 1999 (selanjutnya disebut UUTPK), pengertian korupsi tidak secara tegas dinyatakan, namun diberi istilah "penyimpangan keuangan negara atau perekonomian negara" sehingga meliputi perbuatanperbuatan memperkaya diri sendiri atau orang lain atau suatu korporasi secara "Melawan Hukum" dalam pengertian formal dan materiil, sehingga juga mencakup perbuatan tercela yang menurut perasaan keadilan masyarakat harus dituntut dan dipidana walau tidak diatur sebagai perbuatan kejahatan dalam suatu perundang-undangan. Wujud perbuatan korupsi terlihat dalam pasal 2 ayat (1) dan ayat (2), pasal 3 s.d. pasal 16, pasal 21 s.d. pasal 24 UUTPK.

Kesulitan yang acap kali muncul ketika menyangkut pemahaman terhadap unsur "melawan hukum" (weder-rechtelijk). Mengenai unsur "melawan hukum", Penjelasan Pasal 2 ayat (1) UU Antikorupsi menegaskan bahwa :

"Yang dimaksud dengan 'secara melawan hukum' dalam pasal ini mencakup perbuatan melawan hukum, dalam arti formil maupun dalam arti materiil, yakni meskipun perbuatan tersebut tidak diatur dalam peraturan perundang-undangan, namun apabila perbuatan tersebut dianggap tercela karena tidak sesuai dengan rasa keadilan atau norma-norma kehidupan sosial dalam masyarakat, maka perbuatan tersebut dapat dipidana......"

Penjelasan Pasal 2 ayat (1) UU Antikorupsi tersebut telah dinyatakan "tidak mempunyai kekuatan hukum mengikat oleh Mahkamah Konstitusi. Mahkamah Konstitusi melalui Putusannya Nomor 003/PUU-IV/2006 yang diputuskan pada hari Senin, 24 Juli 2006, di antaranya memutuskan bahwa: Menyatakan Penjelasan Pasal 2 ayat (1) Undang-undang Republik Indonesia Nomor 31 Tahun 1999, tentang Pemberantasan Tindak Pidana Korupsi sebagaimana telah diubah dengan Undang-undang Nomor 20 Tahun 2001, tentang Perubahan atas
Undang-undang Nomor 31 Tahun 1999, tentang Pemberantasan Tindak Pidana Korupsi (Lembaran Negara Republik Indonesia Tahun 2001 Nomor 134, Tambahan Lembaran Negara Republik Indonesia Nomor 4150) sepanjang frasa yang berbunyi, "Yang dimaksud dengan 'secara melawan hukum' dalam Pasal ini mencakup perbuatan melawan hukum dalam arti formil maupun dalam arti materiel, yakni meskipun perbuatan tersebut tidak diatur dalam peraturan perundang-undangan, namun apabila perbuatan tersebut dianggap tercela karena tidak sesuai dengan rasa keadilan atau norma-norma kehidupan sosial dalam masyarakat, maka perbuatan tersebut dapat dipidana" bertentangan dengan Undang-undang Dasar Negara Republik Indonesia Tahun 1945; Menyatakan Penjelasan Pasal 2 ayat (1) Undang-undang Republik Indonesia Nomor 31 Tahun 1999, ten-tang Pemberantasan Tindak Pidana Korupsi sebagaimana telah diubah dengan Undangundang Nomor 20 Tahun 2001, tentang Perubahan atas Undang-undang Nomor 31 Tahun 1999, tentang Pemberantasan Tindak Pidana Korupsi (Lembaran Negara Republik Indonesia Tahun 2001 Nomor 134, Tambahan Lembaran Negara Republik Indonesia Nomor 4150) sepanjang frasa yang berbunyi, "Yang dimaksud dengan 'secara melawan hukum' dalam pasal ini mencakup perbuatan melawan hukum dalam arti formil maupun dalam arti materiel, yakni meskipun perbuatan tersebut tidak diatur dalam peraturan perundang-undangan, namun apabila perbuatan tersebut dianggap tercela, karena tidak sesuai dengan rasa keadilan atau norma-norma kehidupan sosial dalam masyarakat, maka perbuatan tersebut dapat dipidana" tidak mempunyai kekuatan hukum mengikat.

Putusan Mahkamah Konstitusi tersebut hanya mencabut Penjelasan Pasal 2 ayat (1) UU Antikorupsi, yang pada dasarnya merupakan dasar dapat diterapkannya sifat melawan hukum dalam arti materiel positif. Putusan Mahkamah Konstitusi tersebut sama sekali tidak menyinggung berlakunya sifat melawan hukum dalam pengertian materiel negatif, yang telah menjadi yurisprudensi Mahkamah Agung. Berdasarkan hal tersebut, maka berlakunya sifat melawan hukum dalam arti materiel negatif terhadap tindak pidana korupsi juga problematis.

Secara teoritis atau dalam doktrin hukum pidana, di damping dibedakan antara sifat melawan hukum formal (formele wederrechtelijkheid) dan materiil (materiele wederrechtelijkheid), juga dibedakan 
antara sifat melawan hukum dalam pengertian materiil yang negatif dan positif. Dianutnya sifat melawan hukum materiil berarti melibatkan penilaian berdasarkan "perasaan hukum" warga masyarakat, di samping secara formal memenuhi semua unsur yang tercantum dalam rumusan tindak pidana. "Perasaan hukum" masyarakat yang dimaksud adalah anggapan masyarakat perbuatan tersebut sebagai perbuatan yang tercela karena menimbulkan kerugian negara dan masyarakat (fungsi positif) atau sebaliknya perbuatan tersebut dianggap memberi manfaat pada masyarakat (salah satu kategori fungsi negatif).

Sifat melawan hukum dalam pengertian materiil yang negatif, berarti apabila secara materiil perbuatan tersebut tidak bertentangan dengan hukum (kendati perbuatan tersebut masuk dalam perumusan undang-undang). Sebaliknya, sifat melawan hukum dalam pengertian materiil yang positif berarti, tidak dilarang oleh undang-undang, tetapi berdasarkan "perasaan hukum" masyarakat perbuatan tersebut dianggap keliru. Rumusan UU Antikorupsi yang semula mengesankan dianutnya ajaran sifat melawan hukum materiil dalam fungsinya yang positif dan dengan demikian memberi ruang interpretasi yang lebih luas lagi, yang memunculkan kekhawatiran membahayakan kepastian hukum, kini tidak lagi setelah muncul Putusan Mahkamah Konstitusi Nomor 003/PUUIV/ 2006 tersebut.

Ini berarti ruang yang semula longgar bagi penyidik, penuntut umum, dan hakim kembali dipersempit oleh Mahkamah Konstitusi. Sebaliknya, sifat melawan hukum materiil dalam fungsinya yang negatif masih terbuka untuk dipakai oleh terdakwa sebagai alasan pembenar. Artinya, sifat melawan hukum materiil yang dianut oleh UU Antikorupsi dimaknai dalam sifatnya yang negatif, di samping sifat melawan hukum dalam pengertian formal.

Dalam UU nomor 20 tahun 2001, paradigma pengertian korupsi bergeser kepada: pemberian suap (gratifikasi); yang menerima suap; perbuatan curang dari pemborong/ahli bangunan yang membahayakan keamanan orang. Sedangkan Modus Tidak Pidana Korupsi dapat berupa penggunaan anggaran yang tidak sesuai peruntukan; markup pembiayaan anggaran; pemalsuan anggaran/fiktif; gratifikasi; dan pemberian hadiah.

Undang-undang Nomor 20 tahun 2001 secara spesifik mengatur tindak pidana korupsi dalam bentuk: 1) memberi atau menjanjikan kepada pegawai negeri atau penyelenggara negara (pasal 1 sub a); (2) PNS/Penyelenggara Negara yang menerima pemberian (pasal $1 \mathrm{sub}$ a2); (3) memberi atau menjanjikan kepada hakim/advokat (pasal 6 ayat 1 sub a); (4) Hakim/advokat yang menerima pemberian (pasal 6 ayat 2); (5) perbuatan curang oleh pemborong/ahli bangunan (pasal 7 ayat $1 \mathrm{sub}$ $a, b, c)$; (6) menerima perbuatan curang (pasal 17 ayat 2), (7) PNS/orang lain yang menggelapkan uang atau surat berharga yang disimpan karena jabatannya (pasal 8). (8) PNS atau orang lain yang dengan sengaja memalsu buku-buku atau daftar khusus untuk pemeriksaan administrasi (pasal 9); (9) PNS atau orang lain yang menggelapkan, menghancurkan, merusak barang, akta, surat atau daftar yang dipakai untuk pembuktian (pasal 10 sub a,b,c); (10) PNS/Penyelenggara Negara yang menerima hadiah yang berhubungan dengan kekuasaan dan jabatannya (pasal 11).

Secara teoritik, Syed Husein Alatas membagi korupsi dalam 7 (tujuh) tipologi atau bentuk jenis korupsi, yaitu (Mulyana W. Kusuma, 2001: 141); (1) Korupsi transaktif (transactive corruption), merupakan jenis korupsi yang menunjukan adanya kesepakatan timbal balik antara pemberi dan penerima demi keuntungan kedua belah pihak. Biasanya korupsi ini terjadi antara pelaku usaha dengan aparatur pemerintah melalui kebijakan yang dibuatnya; (2) Korupsi perkerabatan (nepotistic corruption), merupakan korupsi yang menyangkut penyalahgunaan kewenangan dan kekuasaan untuk berbagai keuntungan bagi kerabat dan temantemannya; (3) Korupsi yang memeras (extortive corruption), adalah korupsi yang dipaksakan kepada pihak tertentu yang biasanya disertai dengan ancaman, tekanan ataupun bentuk paksaan lainnya; (4) Korupsi investif (investive corruption), merupakan korupsi dalam membentuk memberikan barang dan jasa kepada pihak lain demi keuntungan di masa depan; (5) Korupsi defensif (defensive corruption) adalah korupsi dimana pihak yang dirugikan terpaksa ikut terlibat di dalamnya sehingga yang bersangkutan justru menjadi korban perbuatan korupsi; (6) Korupsi otogenik (otogenic corruption) yaitu korupsi yang dilakukan seorang diri, tanpa ada pihak lain yang terlibat; (7) Korupsi suportif (supportive corruption), adalah korupsi yang terjadi dalam bentuk dukungan dengan cara mendiamkan atau berpura-pura tidak tahu atau ikut bersama-sama menikmati hasil korupsi. 


\section{AKUNTABILITAS KEBIJAKAN DAN POTRET KORUPSI DI INDONESIA}

Secara etimologis, kebijakan berasal dari kata bijak artinya "selalu menggunakan akal budi, pandai atau mahir" (Basrief Arief, 2006: 7), sedangkan kebijakan adalah "rangkaian konsep asas yang menjadi garis besar dan dasar rencana dalam pelaksanaan suatu pekerjaan atau cara bertindak dari pemerintah atau organisasi, dalam menghadapi atau menangani suatu masalah" atau dapat juga diartikan "sebagai pernyataan cita-cita, tujuan atau prinsip atau maksud sebagai garis pedoman untuk manajemen dalam usaha mencapai sasaran"(Kamus Besar Bahasa Indonesia, 1990). Dalam bahasa Inggris bijak disebut smart, exprienced, capable, wise, sedangkan kebijakan adalah inteligence atau wisdom (Kamus Lengkap Inggris-Indonesia,1990), berarti kepandaian atau kemahiran, dengan kata lain kebijakan lazim diartikan policy (John M. Echols, 2002), sedangkan dalam bahasa Belanda disebut beleid (Maejanne Termorshuzan, 2002). Jika Policy dari sudut bahasa identik dengan beliedsregel artinya adalah peraturan, tata pemerintahan atau politik, sedangkan beleid adalah kebijakan sebagai upaya mengentaskan peraturan perundang-undangan dimaksud. Thomas R Dye memberikan pengertian kebijakan (publik) dengan dimensi yang lebih luas yaitu sebagai "what ever the government choose to do or not to do". Dalam konteks ini, setiap perbuatan yang dipilih oleh pemerintah untuk dilakukan atau tidak dilakukan adalah sebuah kebijakan. Oleh karena itu, wujud kebijakan dapat berupa produk legislasi yaitu UU dan Perda atau produk regulasi yaitu Peraturan Pemerintah, Peraturan Presiden, Peraturan Menteri, Peraturan Kepala Daerah dan peraturan/keputusan lembaga negara lainnya.

Dalam kerangka tata kelola pemerintahan yang baik, setiap kebijakan dituntut akuntabilitasnya. Tata kelola pemerintahan yang baik menuntut setiap pejabat publik baik politisi, birokrasi dan aparatur penyelenggara pemerintahan wajib bertanggung jawab dan mempertanggungjawabkan kepada publik segala sikap, perilaku dan kebijakannya dalam melaksanakan tugas pokok, fungsi, peranan dan kewenangan yang diberikan kepadanya. Akuntabilitas merupakan persyaratan mendasar untuk mencegah penyalahgunaan kewenangan yang didelegasikan dan menjamin kewenangan dapat diarahkan pada pencapaian tujuan institusional dengan tingkat efisiensi, evektivitas, kejujuran dan hasil yang sebesar mungkin.
Akuntabilitas merupakan kewajiban untuk memberikan pertanggungjawaban atau menjawab atau menerangkan kinerja atau tindakan seseorang/ badan hukum atau pimpinan organisasi kepada pihak yang memiliki hak atau kewenangan untuk meminta keterangan atau dipertanggungjawabkan (IGM Nurdjana, 2010: 210).

Beberapa contoh potret korupsi yang terjadi di Indonesia, yang bersumber dari kebijakan ataupun perbuatan individual antara lain kasus BLBI, bailout Bank Century, pengadaan barang dan jasa, penggelembungan anggaran (mark up), penyusutan kualifikasi (bestek), penyalahgunaan prosedur tender, manipulasi dalam proses perencanaan anggaran, penggunaan anggaran tidak sesuai dengan pos belanja, penganggaran tidak tepat sasaran, munculnya berbagai pos siluman, penyimpangan berbagai jenis anggaran akibat kurang kontrol publik, biaya tambahan dalam pengurusan KTP, SIM, sertifikat tanah, surat pemberitahuan pajak tahunan (SPPT), perizinan, kecurangan dalam pelaksanaan tender, proyek fiktif, kuitansi fiktif, kegiatan fiktif, honorarium fiktif, perjalanan dinas fiktif dan tidak sesuai dengan penugasan, dan perbuatan sejenisnya.

Korupsi dengan segala bentuknya di Indonesia saat ini sudah menyerang seluruh sistem sosial sedemikian rupa sehingga yang terjangkit adalah sistem secara total. Nyaris tiada sejengkal ruang pun ketika berhubungan dengan penyelenggaran pemerintahan yang terbebas dari perbuatan koruptif. Dalam kondisi seperti ini, maka menurut Syed Hussein Alatas, akan terjadi apa yang disebut pengaruh korupsi yang menular (metastatic). Dia menekankan bahwa masalah korupsi itu bersifat lintas-sistemik. Karenanya, korupsi melekat pada semua sistem sosial. Entah itu Feodalisme, Kapitalisme, Komunisme, bahkan Sosialisme (SH Alatas, 1987: 13-14). Pada akhir tahun 1960, David H. Bayley pernah menegaskan dalam tulisannya yang diberi judul "The Effect of Corruption in a Developing Nation", bahwa korupsi terdapat dalam bentuk, cara dan jumlah yang tidak terhitung ragamnya. Jumlah dalih untuk melakukan korupsi sama banyaknya dengan jumlah cara pengaruh pemerintahan pada perorangan-perorangan dalam masyarakat. Kesempatan untuk melakukan korupsi sama banyaknya dengan jumlah peranan yang dapat dijalankan dalam pemerintahan. Dicontohkannya, korupsi bisa terjadi pada pembagian lisensi ekspor, keputusan untuk mengadakan penyelidikan kasus- 
kasus kriminal, usaha mendapatkan berkas laporan suatu perkara pengadilan, penerimaan calon-calon mahasiswa di suatu universitas, pemilihan caloncalon jabatan pemerintahan dan persetujuan kontrak serta pelaksanaan segala sesuatu (Muchtar Lubis, et. all, 1995: 95-96).

Awal dari terjadinya korupsi adalah adanya penyimpangan-penyimpangan yang dimulai dari perencanaan anggaran sampai dengan pertanggung-jawaban anggaran. Bentuk-bentuk penyimpangan dapat bermacam-macam, baik yang berupa penyimpangan administrasi maupun yang berindikasi pidana. Kamus Besar Bahasa Indonesia (KBBI) mendefinisikan penyimpangan berarti proses, cara, perbuatan menyimpang atau menyimpangkan. BPK menyatakan penyimpangan keuangan sebagai segala sesuatu yang menimbulkan perbedaan antara yang seharusnya dengan realisasi angka yang ada dalam laporan keuangan. Pengertian lain, "penyimpangan adalah suatu perbuatan yang tidak wajar yang disengaja dengan maksud mempengaruhi kepercayaan orang lain untuk menyerahkan beberapa hal yang berharga."

Jenis-jenis Penyimpangan yang terjadi antara lain: (a) penyimpangan terhadap ketertiban dan ketaatan pada peraturan perundang-undangan; (b) penyimpangan terhadap kehematan dan efisiensi; dan (c) penyimpangan terhadap efektivitas. Penyimpangan pada proses pengelolaan keuangan daerah, antara lain pada berbagai kegiatan musrenbang. Titik rawan penyimpangan, antara lain dalam tahap perencanaan (penyusunan anggaran), tahap pembahasan, tahap pelaksa-naan, tahap pengawasan dan evaluasi. Panduan Praktis Monitoring Keuangan merupakan salah satu alat atau instrumen pemantauan keuangan. Korupsi sulit diberantas jika sistem pengelolaan keuangan masih belum diubah atau diperbaiki. Akuntabilitas dan transparansi harus menjadi "roh" untuk melakukan perubahan dalam pengelolaan keuangan, menuju good governance dan clean govenment.

Eksistensi UU nomor 17 tahun 2003 tentang Keuangan Negara, UU nomor 1 tahun 2004 tentang Perbenda-haran Negara, UU nomor 25 tahun 2004 tentang Sistem Perencanaan Pembangunan Nasional, dan UU nomor 32 tahun 2004 tentang Pemerintahan Daerah harus dipahami dan dicermati dalam kaitannya dengan penyelenggaraan pemerintahan dan pembangunan di pusat dan daerah. Beberapa kelemahan sistem pengelolaan keuangan pemerintah selama ini adalah masalah peraturan perundang-undangan, perencanaan dan penganggaran, perbendaharaan, dan auditing. Keberadaan beberapa undang-undang ini diharapkan dapat mengubah dan memperbaiki infrastruktur perencanaan dan penganggaran dan pengelolaan keuangan negara, antara lain perencanaan dan penganggaran pemerintah, penyatuan anggaran dan penerapan medium term expenditure framework dalam penyusunan anggaran, pelaksanaan sistem penganggaran berbasis kinerja, perubahan klasifikasi anggaran, penegasan peran lembaga legislatif dan pemerintah dalam proses penyusunan dan penetapan anggaran, dan penegasan pengaturan kekuasaan atas pengeloaan keuangan negara. Sasaran akhir adalah perwujudan good governance dan clean government.

Secara riel, fenomena korupsi di Indonesia dapat digambarkan sebagai berikut: (1) Indeks Persepsi Korupsi (IPK) Indonesia dari 2003 ke 2004 dan 2005 menunjukkan perbaikan, yaitu dari $1,9 \mathrm{ke}$ 2,0 dan 2,2. Urutan berubah dari 12 ke 10 dan 20, sedangkan berdasarkan kelompok negara-negara terkorup beranjak naik menjadi ke-5 dan ke-6. Pada 2005, IPK Indonesia berada pada urutan 137 dari 159 negara dengan skor IPK 2,2. Tahun 2004 tercatat 1,9 dan tahun 2002 tercatat 1,9. Jika IPK dianggap nilai, maka perolehan nilai kita saat ini masih MERAH atau E. IPK dari Transparency International (TI) di Berlin merupakan peringkat negara-negara yang disurvei berdasarkan tingkat korupsi yang melibatkan pejabat publik dan politisi. IPK merupakan indeks gabungan, menggambarkan aneka data tentang korupsi berdasarkan survai yang dilakukan oleh berbagai institusi terpercaya. Survei ini mencerminkan persepsi masyarakat (pebisnis) dan analis dari seuruh dunia, termasuk para pakar yang tinggal di negara-negara yang dievaluasi; (2) Lembaga yang harus dibersihkan lebih dahulu pertama ditujukan kepada pembersihan lembaga peradilan, diikuti instansi pajak, polisi dan DPRD. Ini menunjukkan harapan terbesar pebisnis dalam memberantas korupsi dalam penegakan hukum. Artinya, kalau lembaga peradilan bersih, maka di mata responden, penegakan hukum dan pemberantasan korupsi dapat berjalan dengan baik, dan hal itu akan mengurangi korupsi. Pengawasan DPRD juga penting, sehingga pembersihan DPRD dari situasi korup merupakan prioritas yang harus dilakukan (Survai TII, 2004). 
GAMBARAN UPAYA PEMBERANTASAN KORUPSI SEJAK TAHUN 1967

Pada tahun 1967, Soeharto yang baru menjadi Presiden RI, membentuk Tim Pemberantas Korupsi dipimpin Mayjen Sutopo Juwono. Sejak saat itu, berbagai lembaga sejenis silih berganti. Tim Pemberantas Korupsi yang dibentuk berdasarkan Keppres nomor 228 tahun 1967 tanggal 2 Desember 1967 dan UU 24/1960, Ketua Tim Sugiharto Jaksa Agung, Penasehat Menkeh dan Panglima ABRI, bertugas membantu pemerintah memberantas korupsi dengan tindakan preventif dan represif. Komisi Empat yang dibentuk berdasarkan Keppres nomor 12 tahun 1970, 31 Januari 1970, terdiri atas Wilopo, Kasimo, Anwar Tjokroaminoto, Johannes, serta Sutopo Juwono, bertugas menghubungi pejabat atau instansi pemerintah, swasta, sipil, dan militer, memeriksa dokumen administrasi pemerintahan, menangani kasus Pertamina, penebangan hutan, defisit Bulog tahun 1971, menyederhanakan struktur administrasi negara, dan menyarankan agar atasan memberi contoh penegakan hukum. Komite Anti Korupsi (KAK) 1970, diisi Angkatan 66 (Akbar Tanjung, Mishael Setiawan, Thoby Muis, Jacob Kendang, Imam Waluyo, Tutu TW, Soerowijono, Agus Jun Batuta, M. Surachman, Alwi Nurdin, Lucas Luntungan, Asmara Nababan, Sjahrir, Amir Karamoy, E. Pesik, Vitue, Mengadang Napitupulu, dan Chaidir Makarim). KAK diskusi dengan Presiden membahas masalah penanganan korupsi. OPSTIB dan Inpres 9/1977, Menpan sebagai koordinator tingkat pusat, operasional Pangkopkamtib, Kapolri, Jaksa Agung, para Irjen, Laksusda, Kadapol, dan Kejati, menangani pungutan liar, uang siluman di pelabuhan, aparat pemerintahan, penanganan kasus korupsi di Mabes Polri, kasus Pluit Endang Wijaya, dan kasus Arthaloka. Tim Pemberantas Korupsi pada tahun 1982 dihidupkan lagi (anggotanya terdiri atas Sumarlin, Sudomo, Mudjono, Ali Said, Ismail Saleh, Awaludin Djamin). Tim Gabungan Pemberantasan Tindak Pidana Korupsi (TGTPK), UU 28/1999 tentang Penyelenggaraan Negara yang Bersih dan Bebas dari KKN, dilanjutkan dengan UU 31/1999, dan UU 20/2001, kemudian ditetapkan Perpu 19/2000, Ketua Adi Andojo, Soetjipto, didukung 25 anggota Kejaksaan dan Kepolisian. Beberapa dokumen terkait dihasilkan, antara lain tatacara pemeriksaan kekayaan penyelenggara negara (PP 65/1999), tatacara pelaksanaan peran serta masyarakat dalam penyelenggaraan negara
(PP 68/1999), dan tim gabungan pemberantasan tindak pidana korupsi (PP 19/2000). Komisi Pemeriksa Kekayaan Penyelenggara Negara (KPKPN) 1999, yang diketuai oleh Jusuf Sjakir dan anggota, rekrutmennya diproses me-lalui DPR. Lembaga ini melebur ke KPTPK/KPK berdasarkan UU nomor 30 tahun 2002 tentang KPTPK. Lahirnya KPK, 27 Desember 2003 (UU 30/2002) membawa segudang harapan masyarakat. Ketua KPK (Taufiequrachman Ruki) dibantu para Wakilnya (Erry Ryana Hardjapamekas, Tumpak H Panggabean, Sjahruddin Rasul, Amien Sunaryadi) dan jajarannya diharapkan berperan nyata dalam pemberantasan korupsi di atas Rp 1 miliar.

Menindaklanjuti Inpres nomor 5 tahun 2004 tentang Percepatan Pemberantasan Korupsi pada semua tingkatan dan wilayah pemerintahan, Instansi pemerintah pusat dan daerah (tertentu) menerima sepuluh instruksi umum dan sebelas instruksi khusus kepada pejabat instansi tertentu. Instruksi Umum meliputi kewajiban membuat laporan harta kekayaan penyelenggara negara (LHKPN), membantu KPK dalam pelaporan dan pemeriksaan LHKPN, membuat penetapan kinerja, meningkatkan kualitas pelayanan publik, menetapkan program dan wilayah bebas korupsi (dituangkan ke dalam pakta integritas), melaksanakan Keppres 80/2003 tentang Pengadaan Barang atau Peralatan Pemerintah (penerapan e-procurement atau e-government), menerapkan kesederhanaan hidup, memberikan dukungan maksimal terhadap penindakan korupsi oleh penegak hukum, kerjasama dengan KPK dalam pengkajian sistem yang berpotensi korupsi, dan meningkatkan pengawasan dan pembinaan aparatur untuk meniadakan perilaku koruptif. Selain itu Presiden juga memberikan Instruksi Khusus yang berisi: kajian dan uji coba penerapan e-Procurement (Menko Perekonomian, Menkeu, MenPPN/Kepala Bappenas), pengawasan perpajakan, kepabenan dan cukai, PNBP (Penerimaan Negara Bukan Pajak) dan anggaran, untuk menghilangkan kebocoran (Menkeu), Rencana Aksi Nasional Pemberantasan Korupsi atau RAN-PK (MenPPN/ Kepala Bappenas), kebijakan peningkatan kualitas pelayanan publik, penetapan kinerja, penerapan prinsip-prinsip tata kepemerinahan yang baik, pengkajian sistem kepegawaiana negara, dan koodinasi-monitoring-evaluasi Inpres ini (Menpan), menyusun amandemen undangundang pemberantasan korupsi, menyusun peaturan perundang-undangan yang terkait dengan 
pemberantasan tindak pidana korupsi(Menhukham), implementasi prinsip tata kelola perusahaan yang baik (MenBUMN), pendidikan substansi semangat dan perilaku anti korupsi (Mendiknas), sosialisasi pendidikan anti korupsi dan kampanye anti korupsi (Menkominfo), mengoptimalkan penyidikan, sanksi tegas, dan kerjasama penegakan hukum dan pengembalian kerugian keuangan negara akibat tindak pidana korupsi (Jaksa Agung dan Kapolri), serta menerapkan prinsip-prinsip tata kepemerintahan yang baik, pelayanan publik, meniadakan pungutan liar, dan bersama DPRD melakukaan pencegahan kebocoran keuangan negara, APBN/APBD (Gubernur dan Bupati/Walikota). Sejalan dengan itu, tingkatkan akuntabilitas, transparansi, jangan menyalahgunakan wewenang, tegakkan hukum, hilangkan kesempatan dan niat berbuat korupsi.

\section{MEMBUDAYAKAN PERILAKU ANTI KORUPSI DAN KOMITMEN MORAL DENGAN PAKTA INTEGRITAS}

Dalam 10 tahun terakhir, gelombang perubahan yang menakjubkan telah terjadi di Indonesia. Pemerintah telah memilih jalan untuk melaksanakan program desentralisasi secara besarbesaran dan telah melaksanakan pemilihan umum secara langsung untuk memilih presiden, gubernur, bupati dan walikota. Hal ini haruslah dilihat sebagai proses transisi secara damai dari rezim otoriter kepada rezim demokrasi yang diikuti pula dengan perubahan-perubahan kelembagaan dan transformasi regulasi.

Dalam konteks inilah masalah korupsi di Indonesia perlu untuk dikaji. Korupsi bukanlah sesuatu yang khas Indonesia. Hampir dikebanyakan negara korupsi selalu terjadi. Korupsi merebak hampir di semua negara di dunia baik negara industri maupun negara berkembang. Survei yang dilakukan oleh Transparansi Internasional menunjukan bahwa Indonesia merupakan salah satu negara terkorup di dunia. Dalam bidang pemberantasan korupsi, skor Indonesia hanya sejajar dengan Nigeria dan Banglades dan tertinggal jauh apabila dibandingkan dengan Philipina maupun Malaysia (World Bank, 2004: 17).

Hasil survey ini mencerminkan transparansi yang lebih besar mengenai korupsi di Indonesia dan menunjukkan bahwa masyarakat Indonesia menjadi salah satu masyarakat yang terbuka. Masyarakat mengakui bahwa Korupsi secara obyektif terjadi di berbagai sektor dan masyarakat juga berpendapat bahwa korupsi merupakan kejahatan yang harus dibasmi. Korupsi merupakan ancaman yang besar bagi transisi politik dan ekonomi di Indonesia karena korupsi melemahkan kemampuan negara untuk menyediakan barang-barang publik dan mengurangi kredibilitas negara di mata rakyat. Dalam jangka panjang korupsi merupakan ancaman bagi keberlangsungan demokrasi.

Survei nasional yang dilaksanakan oleh Partnership For Governance Reform in Indonesia menyajikan sumber informasi yang kaya tentang persepsi 2.300 rumah tangga, pejabat publik dan pengusaha. Hasil survey mengungkapkan bahwa $75 \%$ responden berpendapat bahwa korupsi sangat lazim di sektor publik. Di samping itu, $65 \%$ rumah tangga melaporkan telah mengalami secara langsung dan $70 \%$ responden melihat korupsi sebagai "penyakit yang harus diberantas. Survei juga mengungkapkan tingkat kemarahan publik dan kemuakan terhadap korupsi. $80 \%$ responden menghendaki agar pejabat-pejabat yang korup dipenjarakan dan disita kekayaannya. Sebagian kecil dari responden menghendaki pejabat tersebut dipermalukan di depan umum. Nyaris tidak ada dukungan untuk memberikan amnesti atau pengampunan bagi pelaku korupsi di masa lalu (World Bank, 2001: 47).

Survei tersebut menawarkan tiga temuan yang signifikan. Pertama, orang tidak terlalu percaya pada lembaga-lembaga negara. Lembaga-lembaga yang dianggap paling korup termasuk di sektor peradilan (Kepolisian, Pengadilan, Kejaksaan dan Departemen Kehakiman), instansi-instansi pendapatan (Dinas Pabean dan instansi Perpajakan), Departemen Pekerjaan Umum dan Bank Indonesia. Kedua, lembaga-lembaga yang dirangking paling korup juga dianggap kurang efisien dalam penyampaian jasa. Ketiga, survei tersebut memberi wawasan terhadap penyebab-penyebab aktual dari korupsi di Indonesia. Walaupun hasil survey menunjukan kepercayaan yang kuat bahwa korupsi disebabkan oleh gaji pegawai yang rendah, rendahnya moral perorangan, serta tidak adanya pengendali-pengendali dan akuntabilitas, namun analisis data yang cermat menunjukan bahwa empat variabel tersebut berkorelasi dengan manajemen bermutu tinggi, nilai-nilai organisasi yang anti korupsi, manajemen kepegawaian bermutu tinggi dan manajemen pengadaan barang bermutu tinggi (World Bank, 2001: 47).

Sebagai warisan yang sudah berkembang sejak 
jaman VOC, pemberantasan korupsi diyakini akan sulit dilakukan karena akan menentang kepentingankepentingan kelompok yang kuat, terorganisir secara rapi dalam kelompok-kelompok yang saling menguntungkan. Terjadinya distorsi-distorsi secara sistematis dalam struktur yang menghalalkan sistem insentif tidak resmi (komisi, suap, uang pelicin) telah memungkinkan korupsi tumbuh dengan subur. Untuk membangun budaya anti-korupsi, diperlukan penataan ulang struktur-struktur dan sistem insentif sehingga mampu mengubah cara pengambilan keputusan masyarakat sehingga mengubah pula perilaku masyarakat dan aparatur birokrasi. Dalam suatu masyarakat yang bebas korupsi akan tergambar suasana sebagai berikut: (1) Birokrasi sebagai Pelayan publik merasa bertanggung jawab atas pelayanan mereka, merasa takut untuk memungut biaya tidak resmi dan akan mendapatkan insentif resmi karena bertindak jujur; (2) Masyarakat menganggap aturan-aturan akan ditaati sehingga masyarakat memposisikan perilakunya dalam kerangka peraturan tersebut; (3) Masyarakat tidak perlu membayar insentif tidak resmi (komisi, suap, uang pelicin) karena mengetahui bahwa tanpa membayarpun akan dilindungi hak-haknya untuk mendapatkan pelayanan public yang berkualitas.

Pengalaman di negara maju menunjukan bahwa upaya untuk membangun perilaku antikorupsi memerlukan waktu yang lama dan komitmen yang kuat dari para pemimpinnya serta pengawasan terus menerus dari masyarakat dan media massa. Oleh karena itu mengharapkan Indonesia mampu memberantas korupsi dan membudayakan perilaku antikorupsi dalam waktu singkat, adalah harapan yang berlebihan. Dibutuhkan waktu yang lama melalui proses yang disebut oleh Peter L Berger sebagai proses Internalisasi yang dimulai dari bangku-bangku sekolah dasar.

Indonesia menemukan momentum untuk memulai perang melawan korupsi dengan dilakukan perubahan mendasar dalam bidang ketatanegaraan yang memungkinkan dilaksanakannya pemilihan umum yang jujur, bebas, adil dan pemilihan langsung Presiden pada tahun 2004. Hal ini membuat Presiden dan anggota parlemen lebih bertanggung jawab kepada rakyat. Pemilihan Kepala Daerah secara langsung sebagai amanat UU nomor 32 tahun 2004 tentang Pemerintahan Daerah akan meningkatkan akuntabilitas di tingkat lokal. Pergeseran ini diyakini akan membuat para pemegang kekuasaan publik lebih berhati- hati karena masyarakat menuntut akuntabilitas yang lebih besar sebagai imbalan dari suara yang diberikan pada saat pemilihan kepala negara dan kepala daerah.

Pergeseran dalam pemilihan kepala daerah di Indonesia haruslah dilihat sebagai peluang untuk membangun perilaku baru dalam dalam penciptaan keadilan dan pemberantasan korupsi melalui kontrak politik antara calon kepala daerah dan konstituennya. Dari tahun 2005 sampai dengan tahun 2009 telah terjadi pemilihan 33 Gubernur, 349 Bupati dan 91 Walikota (Kompas, 2004: 8). Pada tahun 2010 akan dilakukan 244 pilkada. Oleh karena itu, perubahan sistem ketatanegaraan ini haruslah dijadikan sebagai momentum untuk membangun peningkatan akuntabilitas publik.

Perubahan dalam kerangka akuntabilitas juga tercermin dalam kelengkapan pranata hukum yang disiapkan oleh pemerintah untuk memerangi korupsi dan membangun perilaku anti-korupsi. Pranata hukum ini bersumber dari Ketetapan MPR bulan Oktober tahun 1999 yang menetapkan sebagai tujuan reformasi yaitu suatu aparat negara yang berfungsi dalam penyelenggaraan jasa kepada rakyat yang professional, efisien, produktif, transparan dan bebas dari kolusi, korupsi dan nepotisme. Pranata hukum lainnya adalah UU nomor 28 tahun 1999 tentang Pemerintahan yang bersih dan bebas KKN yang mengharuskan pejabatpejabat publik mengumumkan harta kekayaannya dan menyetujui audit secara berkala, UU nomor 31 tahun 1999 tentang Pemberantasan Tindak Pidana Korupsi yang mendefinisikan secara lebih luas tentang pidana korupsi dan menetapkan gugatan dan prosedur penuntutan, dan amandemen UU tersebut melalui UU nomor 20 tahun 2001 yang meletakan beban pembuktian kepada terdakwa. Selain itu juga sudah diundangkan UU tentang Pencucian Uang dan UU nomor 30 tahun 2002 tentang Komisi Anti Korupsi. Dari segi pengelolaan Keuangan Negara telah pula diundangkan UU nomor 17 tahun 2003 tentang Keuangan Negara, UU nomor 1 tahun 2004 tentang Perbendaharaan Negara dan UU nomor 15 tahun 2004 tentang Tatacara Pemeriksaan dan Pertanggungjawaban Keuangan Negara. Dari uraian di atas, dapat diketahui bahwa pranata hukum di Indonesia sudah cukup memadai untuk melakukan pemberantasan korupsi dan membangun perilaku anti korupsi.

Dari segi kelembagaan, selain lembaga-lembaga konvensional dalam penegakan hukum seperti 
Kejaksaan dan Kepolisian, telah pula dibentuk Komisi Ombusman Nasional yang bertugas menangani pengaduan-pengaduan, Komisi Pemberantasan Korupsi (KPK) yang bertugas secara khusus untuk menangkap dan memeriksa pelaku korupsi dan Pusat Pelaporan dan Analisis Transaksi Keuangan (PPATK) yang bertugas untuk memantau transaksi yang mencurigakan dan melaporkan transaksi tersebut kepada Jaksa Agung.

Upaya untuk mencegah tindak pidana korupsi di berbagai Departemen dan Lembaga Pemerintah Non Departemen dibangun melalui proses pembudayaan perilaku antikorupsi yang di "bungkus" melalui Pakta Integritas. Pakta Integritas merupakan Keinginan Bersama menciptakan kepemerintahan yang baik, bersih, dan berwibawa, mendambakan penegakan hukum, pelaksanaan reformasi birokrasi menyeluruh, pelaksanaan prinsip-prinsip good governance, dan meningkatnya pelayanan publik ke arah pelayanan prima. Banyak faktor penyebab korupsi, antara lain tingkat kesejahteraan pegawai masih rendah, sistem pemberantasan KKN belum sempurna, komitmen semua pihak belum kuat, penanganan masih diskriminatif, sanksi tidak tegas, budaya malu makin menipis, dan kepedulian masyarakat rendah.

Tujuan, strategi pelaksanaan dan langkahlangkah pelaksanaan Pakta Integritas menurut Kementrian Pendayagunaan Aparatur Negara adalah se-bagai berikut: (1) Tujuan; (a) memperkuat komitmen bersama dalam pencegahan dan pemberantasan korupsi melalui langkah-langkah yang efektif); (b) menjadikan Kementerian PAN sebagai Role Model pemberantasan korupsi di lingkungan lembaga pemerintah; dan (c) memberikan konribusi terhaap upaya peningkatan Indeks Persepsi Korupsi (IPK) Indonesia, mencapai 5,0 pada 2010. 2). Strategi: (a) meningkatkan disiplin dan melaksanakan kode etik, sumpah jabatan, serta sumpah dan janji PNS yang dilakukan secara bertahap dimuai dari hal-hal yang sederhana; (b) menurunkan perilaku koruptif melalui perbaikan berbagai sistem secara bertahap; (c) memfungsikan forum pemantau independen; (3) Inventarisasi perilaku dan sistem yang menimbulkan peluang korupsi; (4) Peningkatan disiplin pegawai (absensi, pakaian seragam, penggunaan prasarana dan sarana kerja, pengelolaan anggaran, pengadaan barang dan jasa pemerintah, dan tidak memberi atau menerima uang di luar aturan yang berlaku); (5) Pembenahan sistem (sistem dan prosedur, pengadaan barang dan jasa, manajemen SDM, sanksi dan penghargaan, pengelolaan keuangan, akuntabilitas, pengawasan, pelayanan, dan kebijakan); (6) Pembentukan Forum Independen Pemantau Pelaksanaan Pakta Integritas atau Forum untuk Keberhasilan Pakta Integritas (FKPI), bersama dengan TI Indonesia, ICW, dan MTI; (7) Rencana Aksi (jangka pendek, aksi nyata: perumusan modul, penerbitan SE Menpan agar tidak memberi atau menerima sesuatu dalam berurusan dengan Kementerian PAN, penerbitan Permenpan tentang berlaku efektifnya Pakta Integritas Kementerian PAN, 1 April 2006, pencetakan dan penempatan atribut pakta inegritas di tempat strategis Kempan, pengoperasian kotak suara atau saran Pakta Integritas dan penyediaan formulir dukungan pelaksanaan pakta integritas) dan jangka panjag (menuju birokrasi yang bersih, jujur, akuntabel, transparan, dan pelayanan prima). Rencana Aksi Pakta Integritas dapat menggunakan Rencana Aksi Nasional Pemberantasan Korupsi (RAN-PK) yang dibuat Bappenas berkoordinasi dengan lembaga terkait, sebagai acuan atau referensi.

Selain Kementerian Pendayagunaan Aparatur Negara, Departemen yang juga sudah membangun Pakta Integritas adalah Departemen Keuangan. Departemen Keuangan memberi nama dengan "Konsep pulau Intergritas Departemen Keuangan" yang di dalam mengandung prinsip-prinsip (Komarudin, 2006: 1). Prinsip Konvensi Zero Corruption dengan membangun Performance of Public Official, melalui: (a) pemetaan area korupsi berdasarkan resiko tinggi setiap kegiatan (a risk map); (b) perencanaan pemberantasan korupsi pada setiap area yang beresiko (an anti corruption public agenda); (c) keterbukaan agenda kegiatan pejabat secara langsung oleh masyarakat (an online public agenda perangkat elektronik); (d) data base yang dapat diakses oleh masyarakat (data base for public officers - keleluasaan mengetahui performance pejabat pemerintah); (e) website atas informasi pajak yang lebih transparan (website on tax transparency); (f) program akses informasi dan aplikasi (a program on access to information and application); dan (g) penegakan hukum kepada pegawai. Penting, transparansi dan tanggungjawab setiap pejabat kepada masyarakat secara permanen; (2) Harus disusun rencana aksi pulau integritas yang terintegrasi setiap departemen. Area Depkeu adalah anggaran, perbendaharaan, pajak, dan bea cukai. Perlu perhatian mulai perencanaan, penganggaran, 
implementasi budget, pengawasan dan pengendalian dan diupayakan pencairan anggaran lebih banyak di semester I (front loading spending); (3) Pulau Integritas Departemen Keuangan difokuskan pada: (a) Penyusunan peta kegiatan rawan korupsi oleh masing-masing unit kerja, kemudian dibuat recana tindak menyeluruh; (b) Perbaikan sistem informasi teknologi yang terintegrasi dengan koordinasi terpusat, sehingga informasi terbuka; (c) Penerapan pakta inegritas dilakukan bertahap, mulai pejabat/ pegawai tertentu yang melakukan hubungan kerja dengan ma-syarakat, antara lain pengurus keuangan instansi, wajib pajak, dan importir. Peran dan fungsi pengawas intern sangat menentukan dalam pengembangan dan penerapan kegiatan antikorupsi. Aparat dan kondisi lingkungan pengawasan yang bersih, merupakan prasyarat utama berjalannya upaya pemberantasan korupsi.

Upaya membangun Pakta Integritas juga sudah berkembang sampai ke tingkat Pemerintah Daerah. Salah satu pemda yang dengan cepat mengadopsi konsep tersebut adalah Kabupaten Solok. Pakta Integritas Pemerintah Kabupaten Solok dikembangkan dengan diawali identifikasi masalah, faktor penyebab KKN, akibat KKN, solusi berupa komitmen Pemda, komitmen Swasta dalam pengadaan barang dan jasa pe-merintah, pemantauan pelaksanaan pengadaan barang dan jasa pemerintah yang bersendikan pakta integritas, mekanisme pengaduan, resolusi konflik, dan perlindungan saksi, insentif dan penerapannya, penerapan sanksi.

Gamawan Fauzi saat menjadi Bupati Solok mengidentifikasi penyebab KKN antara yaitu gaji dan tingkat kesejahteraan masih rendah, sistem pem-berantasan KKN belum terbangun dengan sempurna, belum ada kesungguhan komitmen yang kuat untuk memberantas $\mathrm{KKN}$, sanksi atas pelanggaran masih ringan, budaya malu makin menipis, dan kepedulian masyarakat atas penegakan hukum masih rendah. Akibat dari KKN antara lain yaitu: motivasi kerja rendah, "ada meja mata air dan air mata", sumpah jabatan hanya ucapan, disiplin dan tanggungjawab rendah, tidak bermoral, diskriminatif, tidak ada niat berprestasi, hilangnya kejujuran, sulit mendaptkan aparat potensial, tidak ada penegakan hukum, tidak transparan, dan tidak ada lagi kepercayaan terhadap pimpinan. Muncul kejadian-kejadian aturan yang diperjualbelikan, pengusaha mempengaruhi pejabat, pemanfaatan kekuasaan, kesenjangan, ketidakadilan, pembenaran terhadap pelanggaran dan penyimpangan, hilangnya ketaatan, panutan dan keteladanan, masyarakat sulit diatur dan diarahkan, partisipasi masyarakat rendah, ketidakjelasan hak dan kewajiban, kesadaran dan tanggung-jawab berbangsa rendah, sistem, mekanisme dan prosedur tidak jalan, adanya mafia kecil-kecilan, aturan tidak dilaksanakan, aturan hanya formalitas dan diskriminatif, karakter dan jati diri hancur.

Pakta Integritas Pejabat Pemerintah Daerah Kabupaten Solok berisi komitmen-komitmen untuk tidak akan melakukan praktik KKN, tidak meminta/ menerima/memberi sesuatu yang bersangkutan dengan jabatan dan pekerjaan, tidak memberi/ menjanjikan akan memberikan sesuatu berkaitan dengan jabatan/pekerjaan, menjamin tidak melakukan pelangggaran atas aturan, menegakkan transparansi, menciptakan lingkungan kondusif, tidak diskriminatif, memberikan informasi selengkap mungkin, memberikan bantuan/dukungan atas upaya pengungkapan praktik suap dan $\mathrm{KKN}$, dan membangkitkan sikap dan perilaku bersih dan anti KKN. Contoh lainnya, Pakta Integritas pengadaan barang dan jasa pemerintah, sosialisasi internal dan eksternal, dan ajakan kepada semua pihak untuk jujur, adil, akuntabel, transparan, dan tidak melakukan perbuatan tindak pidana.

\section{PENUTUP}

Korupsi diyakini secara sungguh-sungguh oleh seluruh bangsa di dunia sebagai penyakit yang harus dihadapi bersama. Upaya pencegahan dan pemberantasan korupsi harus dilakukan secara sistematik, menyeluruh, melibatkan seluruh masyarakat dengan membangun budaya malu apabila melakukan korupsi.

Secara konsep, norma dan rencana, Pemerintah telah mempunyai perangkat yang cukup untuk mencegah dan memberantas korupsi. Karena telah menjalar kedalam seluruh sektor kehidupan, kita semua meyakini bahwa memberantas korupsi pasti akan menghadapi hambatan. Namun demikian, agar kehidupan bangsa ini dapat menjadi lebih sejahtera, tidak ada lagi alasan untuk menerima perilaku yang koruptif. Kita harus membangun budaya hukum baru agar tidak melakukan perbuatan yang bersifat korupstif baik yang bersifat aktif maupun bersifat pasif dengan mendiamkan terjadinya perbuatan koruptif di sekelilingnya. 


\section{DAFTAR PUSTAKA}

Alatas, S.H., 1987, Corruption: Its Nature, Causes and Functions, Terjemahan oleh Nirwono, Jakarta: LP3ES.

Arief, Basrief, 2006, Korupsi dan Upaya Penegakan Hukum, Adika Remaja Indonesia

Departemen Pendidikan dan Kebudayaan, 1990, Kamus Besar Bahasa Indonesia, Jakarta: Balai Pustaka.

Echols, John M., 2002, An English-Indonetion Dictionary, Jakarta: PT Gramedia Pustaka Utama.

Komarudin, 2006, Etika PNS, Bahan Ajar DIKLAT Pengembangan Perilaku dalam Mencegah Kerugian Keuangan Negara, Badan Diklat Dedagri
Kusuma, Mulyana W., 2001, Tegaknya Supremasi Hukum, Bandung: PT Remadja Rosda Karya.

Lubis, Mukhtar, et.al, 1995, Bunga Rampai Korupsi, Jakarta: LP3ES.

Nurdjana, IGM, 2010, Sistem Hukum Pidana dan Bahaya Laten Korupsi, Yogyakarta: Pustaka Pelajar.

Thermorshuzan, Marjanne, 2002, Kamus BelandaIndonesia, Bandung: Jambatan.

World Bank, 2004, Memerangi Korupsi di Indonesia, Memperkuat Akuntabilitas untuk Kemajuan

, 2001, Partnership for Governance Reform in Indonesia, A National Survey of Corruption in Indonesia, Final Report. 